Biochimica et Biophysica Acta, 557 (1979) 112-121

(C) Elsevier/North-Holland Biomedical Press

BBA 78516

\title{
STUDIES ON THE TURNOVER OF PROTEINS OF THE RAT
} ERYTHROCYTE MEMBRANE

\author{
CLAUDE CÔTÉ and JOHN A. JACQUEZ
}

Department of Physiology, The Medical School, The University of Michigan, Ann Arbor, MI 48109 (U.S.A.)

(Received November 30th, 1978)

(Revised manuscript received May 11 th, 1979)

Key words: Leucine incorporation; Protein turnover; (Erythrocyte membrane)

\section{Summary}

The membrane proteins of erythrocytes were labeled by injecting $\mathrm{L}-\left[{ }^{14} \mathrm{C}\right]$ leucine and later $\mathrm{L}-\left[{ }^{3} \mathrm{H}\right]$ leucine into rats, the two injections being 31 days apart. Control animals received the two isotopic forms of L-leucine simultaneously. Deviations in labeling ratio from control patterns were found on sodium dodecyl sulfate-polyacrylamide gel electrophorograms in restricted regions suggestive of turnover or loss of a few small proteins from the membrane between the 31 days. Most of the ghost proteins show no turnover.

\section{Introduction}

Most proteins have been shown to follow exponential decay kinetics [1]. The only known exception to this general rule is the predominant component of the red blood cell, hemoglobin, which is not degraded until the whole cell is removed from the circulation by the reticuloendothelial system; thus, the erythrocyte and its hemoglobin show lifespan kinetics [2]. The work described in this paper was undertaken to determine if membrane proteins from the mature mammalian erythrocyte, a cell which has lost its capacity to synthesize proteins [3], would show turnover, true or apparent [4]. An exchange of membrane proteins with plasma proteins is conceivable, and Landgon [5] has reported that a significant portion of erythrocyte membrane proteins crossreact with antisera to serum $\alpha$-and $\beta$-lipoproteins. However, Carey et al. [6]

\footnotetext{
* Present address: Biozentrum, The University of Basel, CH-4056 Basel, Switzerland.
} 
have recently presented evidence that suggests that Langdon's results are artifacts. For us, the experiments reported here were also a first exploration of the idea that fully differentiated cells might import gene products from other cell types in order to obtain their full complement of structural and functional proteins. We reasoned that if we could demonstrate that some proteins from a cell which has lost its capacity to synthesize proteins show true turnover (see below), such results would imply that these proteins must come from other cell types of the organism.

To study the turnover process of the erythrocyte membrane proteins, we used the double-label technique. In this experimental design, a cohort of red blood cells is labeled with $\mathrm{L}-\left[{ }^{14} \mathrm{C}\right]$ leucine during their maturation in the marrow and some time later, a second cohort is labeled with $\mathrm{L}-\left[{ }^{3} \mathrm{H}\right]$ leucine in the same way. After the second cohort has entered the peripheral blood and after the maturation from reticulocyte to erythrocyte is completed, one would expect that for each cohort, that is for each isotope, the ratio of labeling of membrane proteins to labeling of globin would be the same unless: (1) the amount of label incorporated in the membrane proteins relative to that incorporated in globin during maturation of the two cohorts was different, or (2) some labeled proteins were either lost from and/or incorporated into the plasma membrane during the ageing of the first cohort of cells in the period between the two injections of labeled leucine. The ratio of the ratios of labeling, i.e. (membrane protein $\left.\left({ }^{3} \mathrm{H}\right)\right) /\left(\right.$ globin $\left.\left({ }^{3} \mathrm{H}\right)\right)$ divided by (membrane protein $\left.\left({ }^{14} \mathrm{C}\right)\right) /$ (globin $\left({ }^{14} \mathrm{C}\right)$ ), can also be written as (membrane protein $\left.\left({ }^{3} \mathrm{H}\right)\right) /($ membrane protein $\left.\left({ }^{14} \mathrm{C}\right)\right)$ divided by $\left(\right.$ globin $\left.\left({ }^{3} \mathrm{H}\right)\right) /\left(\right.$ globin $\left.\left({ }^{14} \mathrm{C}\right)\right)$. Thus one expects that the ratio (membrane proteins $\left.\left({ }^{3} \mathrm{H} /{ }^{14} \mathrm{C}\right)\right) /\left(\right.$ globin $\left.\left({ }^{3} \mathrm{H} /{ }^{14} \mathrm{C}\right)\right)$ will be one unless the above events intervene. In this study we use the term true turnover to refer to a situation in which a protein is removed from a defined subcellular compartment and is replaced by new copies. In the steady state no net loss or gain of the protein occurs. This is distinguished from apparent turnover in which a protein is removed from a subcellular compartment but is not replaced.

\section{Materials and Methods}

In vivo labeling of erythrocyte membrane proteins. Male Sprague-Dawley rats weighing 130-140 g were fasted for $36 \mathrm{~h}$, starting $12 \mathrm{~h}$ prior to the first injection of radioactive L-leucine. Control animals received a total of $40 \mu \mathrm{Ci}$ / $100 \mathrm{~g}$ body weight of $\mathrm{L}-\left[{ }^{14} \mathrm{C}\right]$ leucine, and $80 \mu \mathrm{Ci} / 100 \mathrm{~g}$ body weight of L- $\left[{ }^{3} \mathrm{H}\right]-$ leucine; both isotopes were given together in a series of four intraperitoneal injections at 3 -h intervals. The animals were killed 31 days later and the blood was collected and analyzed. Experimental animals were set up at the same time as the controls and the same spacing of injections was followed for each isotope. They received $\mathrm{L}-\left[{ }^{14} \mathrm{C}\right]$ leucine $(40 \mu \mathrm{Ci} / 100 \mathrm{~g})$ first. 31 days later they received $\mathrm{L}-\left[{ }^{3} \mathrm{H}\right]$ leucine $(80 \mu \mathrm{Ci} / 100 \mathrm{~g})$ and were killed ten days after this second series of injections.

Red blood cell ghost preparation. Freshly collected heparinized blood was centrifuged at $840 \times g_{\max }$ for $10 \mathrm{~min}$ at $40^{\circ} \mathrm{C}$. The cells were washed twice by suspension in 10 vols. of cold isotonic saline. Care was taken to remove white blood cells and reticulocytes. The cells were lysed by adding 20 vols. of iso- 
tonic $(0.172 \mathrm{M})$ Tris- $\mathrm{HCl}, \mathrm{pH} 8.0 * 44^{\circ} \mathrm{C}$, and incubating the cell suspension at $44^{\circ} \mathrm{C}$ for $1 \mathrm{~h}$.

The hemolysate was centrifuged at $39000 \times g_{\max }$ for $15 \mathrm{~min}$ at $4^{\circ} \mathrm{C}$. The supernatant was saved for further analysis. The pink pellet was washed by resuspension in 30 vols. of 20 mosM $* *$ sodium phosphate buffer, $\mathrm{pH} 8.0$, $44^{\circ} \mathrm{C}$. The suspension was centrifuged and the supernatant was discarded. The loose translucent major part of the pellet was resuspended by swirling gently and was transferred to a new test tube and was given two additional washes. The tightly packed button which remains at the bottom of the tube is rich in proteolytic activity [7] and was discarded.

Contamination of the ghost preparation. The amount $(\%)$ of hemoglobin remaining bound to the red blood cell membrane was determined with a Beckman DB recording spectrophotometer at $418 \mathrm{~nm}$ (Soret band).

Another method to determine the percent of the intracellular components and the plasma components which are recovered with the red cell ghost preparations was also used. A rat was injected with radioactive L-leucine (L-4,5- $\left[{ }^{3} \mathrm{H}\right]$ leucine) at a dose of $80 \mu \mathrm{Ci} / 100 \mathrm{~g}$ body weight. Ten days later, the rate was killed and the specific activity ( $\mathrm{dpm} / \mathrm{mg}$ protein) of the ghost proteins was determined. The hemolysate minus the ghosts obtained from $2 \mathrm{ml}$ of packed red blood cells was saved and used as the incubation medium to lyse a similar volume of red blood cells from a non-radioactive rat. The ghosts were prepared and the specific activity was determined. The ratio of the specific activity of the ghost preparation from the non-radioactive animal to that from the radioactive animal was used to estimate the degree of contamination of the ghosts by intracellular protein components; this was 0.014 , i.e. $1.4 \%$. Percent retention of intracellular components in the ghost preparation was determined by taking the ratio of total $\mathrm{dpm}$ of the ghosts from the non-radioactive animals to total dpm recovered in the radioactive hemolysate; this was $0.66 \%$.

A similar approach was used to estimate the retention and contamination by plasma components. The plasma from a radioactive animal was mixed in $1: 1$ ratio with a volume of packed, washed red blood cells from a non-radioactive animal. The red cell suspension was incubated at room temperature for 1 or $2 \mathrm{~h}$ with a constant slow mixing action. Following the incubation, the ery throcytes were washed and ghosts were prepared by our standard procedure. The ratio of the specific activity of the ghost preparation from the non-radioactive animal to that from the radioactive animal was used to estimate the degree of contamination by plasma proteins; this was 0.013 , i.e. $1.3 \%$. Of the radioactivity in the plasma $0.03 \%$ was recovered in the ghosts prepared from red blood cells from the non-radioactive animal.

Polyacrylamide gel electrophoresis. Red blood cell ghost suspensions containing approximately $2 \mathrm{mg}$ protein/ml were solubilized by adding $\beta$-mercaptoethanol and sodium dodecyl sulfate (SDS), each to a final concentration of $1 \%$. The sample was mixed and immediately placed in boiling water for $3 \mathrm{~min}$.

Gels were cast in tubes of $1.8 \mathrm{~cm}$ inner diameter and $15 \mathrm{~cm}$ long. The final

* Unless otherwise specified, $\mathrm{pH}$ values refer to room temperature values.

* The ideal milliosmolarity (mosM) was calculated by totaling the concentrations of all ionizable species in the solution, neglecting deviations of the salts from ideal behavior. 
concentrations of the solutions were $\mathrm{T}=5 \%, \mathrm{C}=3.8 \%$ (according to the designation of Hjerten [8]), SDS $=0.05 \%$, phosphate buffer $=0.05 \mathrm{M}$, ammonium persulfate $=0.037 \%$ and TEMED $=0.025 \%$. reservoir buffer $=$ $0.01 \mathrm{M}$ sodium phosphate, $\mathrm{pH} 7.2,0.1 \% \mathrm{SDS}$. Gels were prerun for $60 \mathrm{~min}$ at a current of $8 \mathrm{~mA} / \mathrm{gel}$. The sample was overlayed and the current was set at $8 \mathrm{~mA} / \mathrm{gel}$ and increased to $15 \mathrm{~mA} / \mathrm{gel}$ after the sample had entered the gel. Running time was $20 \mathrm{~h}$.

Counting radioactivity. Aqueous samples were added to a toluene-based scintillation mixture containing $10 \%$ NCS (Amersham/Searle) and $6.3 \%$ Liquiflor. The gels from the SDS-polyacrylamide gel electrophoresis were sliced $(1.8 \mathrm{~mm})$ and each slice was placed in $15 \mathrm{ml}$ of the same scintillation mixture. These were incubated for $24 \mathrm{~h}$ at $37^{\circ} \mathrm{C}$ during which time the gels swelled, and became transparent. Samples and gel slices were counted in a Unilux II scintillation counter with external standard. Standards were always run with each series and dpm were calculated. Counting was carried to at least $2 \%$ accuracy. In double-label counting, the counting efficiency of tritium was $26 \%$, that of carbon-14 was $45 \%$; carbon-14 'spill-over' in the tritium channel was $11 \%$.

Other procedures. Globin was prepared from the ghost-free hemolysate by the procedure of Anson and Mirsky [9] using acidified acetone. Plasma proteins were precipitated from $1 \mathrm{ml}$ of plasma by addition of $4 \mathrm{ml}$ of $95 \%$ ethanol. The precipitate was centrifuged at $250 \times \mathrm{g}$ for $10 \mathrm{~min}$ and was washed once with $75 \%$ ethanol containing L-leucine $(1 \mathrm{mM})$ and $\mathrm{NaCl}(15 \mathrm{mM})$. Protein was determined by the method of Lowry et al. [10] using bovine serum albumin as standard.

Materials. Acrylamide and bisacrylamide were obtained from Kodak Chemical Co., and recrystallized [11]. L-4,5-[ $\left.{ }^{3} \mathrm{H}\right]$ Leucine $(5 \mathrm{Ci} / \mathrm{mmol}), \mathrm{L}-\left[\mathrm{U}-{ }^{14} \mathrm{C}\right]-$ leucine $(283 \mathrm{Ci} / \mathrm{mol})$ and Liquiflor were purchased from New England Nuclear, Boston, MA. All general laboratory chemicals were 'reagent' grade.

\section{Results}

The double-label procedure predicts a ratio of one, (protein $\mathrm{X}\left({ }^{3} \mathrm{H} /{ }^{14} \mathrm{C}\right)$ )/ (globin $\left({ }^{3} \mathrm{H} /{ }^{14} \mathrm{C}\right)$ ), if protein $\mathrm{X}$ shows lifespan kinetics similar to that of globin; if the bulk of the proteins from the ghost fraction of the red blood cells shows lifespan kinetics, this ratio for total ghost proteins is also not expected to differ significantly from one. Table I gives the results obtained on the control (2) and the experimental animals (3). Using the $t$-test the mean ratio (ghost $\left.\left({ }^{3} \mathrm{H} /{ }^{14} \mathrm{C}\right)\right) /$ (globin $\left({ }^{3} \mathrm{H} /{ }^{14} \mathrm{C}\right)$ ) does not differ significantly from 1.00 at the $5 \%$ level for controls; for the experimental animals this ratio differs from 1.00 at the $5 \%$ level but not at the $1 \%$ level of significance. The ratio for the experimentals also differed significantly from that for controls at the $5 \%$ level but not at the $1 \%$ level of significance. However, it should be recalled that the $t$-test depends on the assumption that the variate in question is normally distributed and this assumption is not true for a ratio. For this reason it is safer to use a $1 \%$ level of significance. Therefore we would say that the results only suggest that there might be a small difference in the ratio for the experimental animals. For the plasma proteins the ratio for controls is not significantly different from 1.00; 
TABLE I

ISOTOPE LABELING RATIOS FOR GHOSTS AND FOR PLASMA PROTEINS DIVIDED BY THE LABELING RATIO OF THE GLOBIN FROM 'THE SAME SAMPLE OF BLOOD

The entries have been rounded to three significant figures; four significant figures were carried in the calculations of means.

\begin{tabular}{lll}
\hline $\begin{array}{l}\text { Preparation } \\
\text { Controls }\end{array}$ & Ghost $\left({ }^{3} \mathrm{H} /{ }^{14} \mathrm{C}\right) /$ globin $\left({ }^{3} \mathrm{H} /{ }^{14} \mathrm{C}\right)$ & $\begin{array}{l}\text { Plasma proteins }\left({ }^{3} \mathrm{H} /{ }^{14} \mathrm{C}\right) / \\
\text { globin }\left({ }^{3} \mathrm{H} /{ }^{14} \mathrm{C}\right)\end{array}$ \\
B & 1.03 & 0.99 \\
$\quad$ Mean & 1.02 & 0.98 \\
Experimentals & $1.025 \pm 0.009 *$ & $0.987+0.0025$ \\
A & & \\
B & 1.07 & 10.7 \\
C & 1.10 & 12.1 \\
Mean & 1.09 & 9.5 \\
\hline
\end{tabular}

* S.E.

that for the experimental animals is obviously different. The high value for the ratio for the plasma proteins in experimental animals indicates there is a rapid turnover of the plasma proteins; this observation is in agreement with the findings of many previous studies [12].

Fig. 1 shows a photograph of a Coomassie blue-stained polyacrylamide gel electrophorogram of rat erythrocyte ghost proteins. Fig. 2 presents the ${ }^{3} \mathrm{H} /{ }^{14} \mathrm{C}$ $\mathrm{dpm}$ ratios of ghost proteins as resolved on SDS-polyacrylamide gel electrophoresis divided by the ${ }^{3} \mathrm{H} /{ }^{14} \mathrm{C}$ dpm ratio of the globin prepared from the same sample of erythrocytes. At the top of Fig. 2 is a curve of the tritium labeling of the gel from experimental animal $C$. The curve of tritium labeling follows the same pattern as the spectrophotometric scan of Coomassie blue staining of the gels although the resolution is lower. The first peak corresponds to the three heavy bands close to the origin of the Coomassie blue-stained pattern in Fig. 1; the second and largest peak of the curve of tritium labeling corresponds to the heavy band slightly over one-third of the way down the pattern in Fig. 1.

The gels for which results are plotted in Fig. 2 were not all of the same length so the number of slices/gel is not the same for all gels. In the plots in Fig. 2 all gels have been rormalized to the same length. The variation in ratio for the two controls is shown immediately below the curve of tritium labeling. The bottom three plots show the variation in labeling ratio for the ghost proteins from the experimental animals; with each the values for one of the control gels is also plotted. By visual inspection it appears that the upper portions of the gels from the experimental animals have a pattern of ratios similar to that of the controls. However, in the lower portions of the gels from experimental animals there are many slices that have ratios that are considerably higher than those in the controls. In order to test for differences between the upper and lower portions of the gels a line was drawn by eye that appeared to separate these two regions in the experimental gels; the line fell $64 \%$ of the way down the gels. The control gels were then divided into upper and lower portions at the same place. 

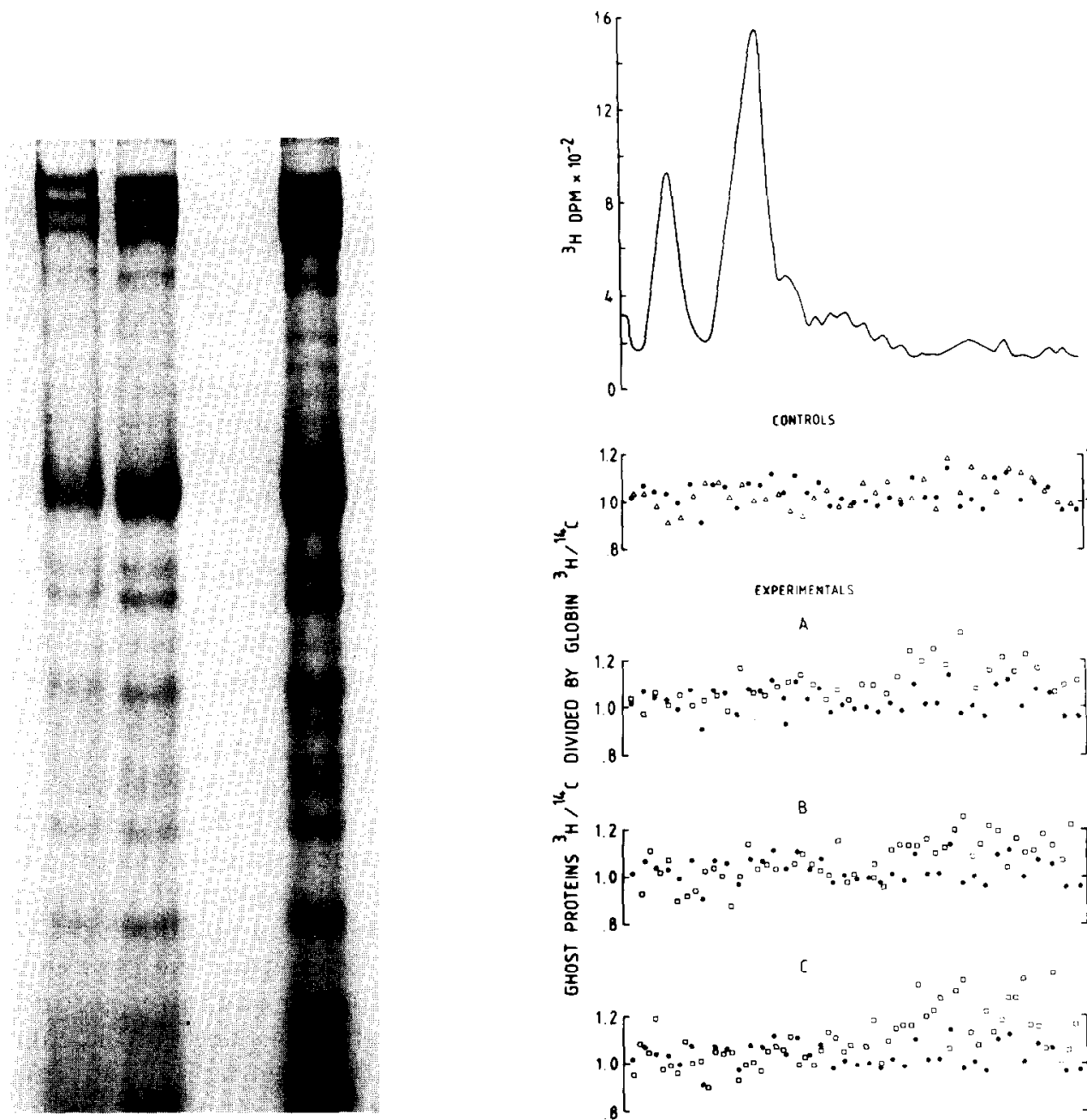

CONTROLS

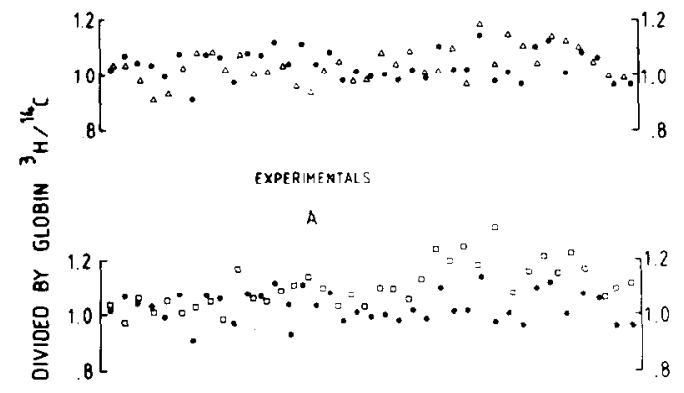

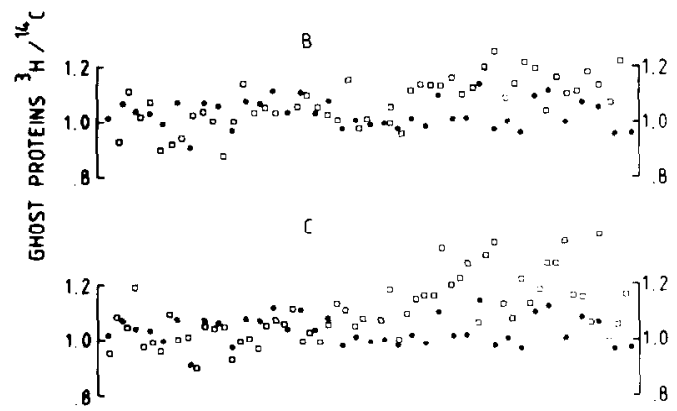

Fig. 1. Photographs of $5 \%$ polyacrylamide slab gel electronhorngrams of rat ery throcyte ghost proteins. The slab gels are $12 \mathrm{~cm}$ long and $1.6 \mathrm{~mm}$ thick. The origin is at the bottom. In order from left to right, the slabs had $20 \mu \mathrm{g}, 40 \mu \mathrm{g}$ and $100 \mu \mathrm{g}$ of ery throcyte ghost protein.

Fig. 2. Electrophoretic patterns of ${ }^{3} \mathrm{H} /{ }^{14} \mathrm{C}$ dpm ratios of ghost proteins from two control animals and three experimental animals. At the top is a curve of the tritium labeling in the gel from experimental animal $\mathrm{C}$. The origin of the gels is at the left. Slices of the gels were $1.8 \mathrm{~mm}$ thick. Each of the symbols, $\bullet, \triangle, \square$, represents the ratio for one slice from a gel. Controls: Animals received a simultaneous injection of $\mathrm{L}-\left[{ }^{3} \mathrm{H}\right]$ leucine $\left(80 \mu \mathrm{Ci} / 100 \mathrm{~g}\right.$ body weight) and $\mathrm{L}-\left[{ }^{14} \mathrm{C}\right]$ leucine $(40 \mu \mathrm{Ci} / 100 \mathrm{~g}$ body weight) and were killed 31 days later. Approximately $6 \mathrm{mg}$ of solubilized proteins were applied to preparative gels (5\% acrylamide). The ${ }^{3} \mathrm{H} / /^{14} \mathrm{C}$ ratio of each slice of the gels from control animals $\mathrm{A}(\bullet$ ) and $\mathrm{B}(\triangle)$ was divided by the ${ }^{3} \mathrm{H} /{ }^{1}{ }^{4} \mathrm{C}$ ratio of their respective globins. Experimentals: Three animals were given $\mathrm{L}-\left[{ }^{3} \mathrm{H}\right] l$ leucine $\left(80 \mu \mathrm{Ci} / 100 \mathrm{~g}\right.$ body weight) 31 days after receiving $\mathrm{L}-\left[{ }^{14} \mathrm{C}\right]$ leucine $(40 \mu \mathrm{Ci} / 100 \mathrm{~g}$ body weight) and were killed ten days later. The data from experimental animals $\mathrm{A}-\mathrm{C}$ are given by the boxes ( $\square$ ). For comparison, the results from one of the control animals $(\bullet)$ are repeated on each plot.

There are a number of problems in finding rigorous statistical tests for differences between ratios in different regions of the polyacrylamide gels. For one the variances of the ratios are not constant; they depend on the extent of labeling in a slice. However, the total protein applied to control and experi- 
mental gels was approximately the same, as were the counts so the variation in the variances is expected to be approximately the same for control and experimental gel slices. Hence we sought balanced tests, that is, tests in which we compared lower and upper portions of experimental and of control gels and then compared the results in the experimental gels with those for the control gels. Another problem with measurements on sequences of gel slices is that there may be significant serial correlations between slices for lags of one or two slices. We have examined the problems encountered in testing ratios of counts in gel slices in another context [13] and that paper should be consulted for details on the problem of serial correlation.

Tests for serial correlation showed no significant serial correlation of lags 1 or 2 between the ratios of slices within the upper or the lower portions of all controls and experimentals so we treated all slices as uncorrelated samples. Table II gives the means and standard deviations of the means of the ratios for the upper and the lower regions of all gels.

Bartlett's test [14] for homogeneity of variances was applied to the entire data set and then to the data for the upper portions and for the lower portions separately. For the combined data set there was significant inhomogeneity of variances at the $1 \%$ level. For the upper portions alone there was no significant inhomogeneity at the $5 \%$ level whereas the variances for the lower portions of the gels showed significant inhomogeneity at the $2.5 \%$ level. Table II shows that the standard errors of the means are larger for the lower portions of the gels for four out of the five gels. In view of these findings the Welch-Aspin test [14] for differences between means when one cannot assume homogeneity of variances was used to test the differences between the means of the upper and lower portions of each gel. For the controls, there was no significant difference for $A$ whereas $B$ just satisfied the test at the $5 \%$ level; for the combined controls there was no significant difference between upper and lower portions at the 5\% level. For the experimental gels, for each one alone and for the combined data, there was a significant difference at better than $0.5 \%$ level. Thus there was a significant difference between the upper and lower portions of the experimental gels but not for the control gels.

It must be remembered that the Welch-Aspin test is not exact in this application because ratios do not follow a normal distribution. One can partly com-

TABLE II

MEANS AND S.E. FOR GEL SLICES

\begin{tabular}{|c|c|c|c|c|c|c|c|c|c|}
\hline & \multicolumn{3}{|c|}{ Slices from upper $64 \%$ of gel } & \multicolumn{3}{|c|}{ Slices from lower $36 \%$ of gel } & \multicolumn{3}{|c|}{ All slices of gel } \\
\hline & No. & Mean & S.E. & No. & Mean & S.E. & No. & Mean & S.E. \\
\hline \multicolumn{10}{|c|}{ Controls } \\
\hline A & 23 & 1.0277 & 0.01045 & 15 & 1.0194 & 0.01608 & 38 & 1.0244 & 0.00885 \\
\hline B & 22 & 1.0066 & 0.01087 & 15 & 1.0520 & 0.01732 & 37 & 1.0250 & 0.01011 \\
\hline \multicolumn{10}{|c|}{ Experimentals } \\
\hline A & 22 & 1.0572 & 0.00990 & 15 & 1.1626 & 0.01811 & 37 & 1.1000 & 0.01265 \\
\hline $\mathrm{B}$ & 29 & 1.0134 & 0.01306 & 22 & 1.1344 & 0.01091 & 51 & 1.0656 & 0.01215 \\
\hline $\mathrm{C}$ & 45 & 1.0359 & 0.01143 & 25 & 1.1872 & 0.02096 & 60 & 1.0989 & 0.01458 \\
\hline
\end{tabular}


pensate for this by reducing the degrees of freedom used in the test; after halving the degrees of freedom the conclusion remains unchanged. However, we also sought a test that was not dependent on assumptions about the distribution of the underlying variate. Using the overall means for each gel we counted the number of slices that fell above and below the overall mean in the upper and in the lower portions. The $\chi^{2}$ test was applied to the $2 \times 2$ contingency tables for the combined counts for the controls and for the combined counts for the experimentals. Again there was no significant difference between the upper and lower portions of the control gels in the distribution of values above and below the overall means; for the experimentals there was a difference at better than the $1 \%$ level of significance.

We conclude that the gels from the experimental animals differ significantly from those from the control animals in the number of high ratios in the lower portions of the gels. Although our initial visual impression was that these were related to two rather broad, weakly staining bands on the electrophorogram, there is enough fluctuation in labeling ratio in the lower portions of the gels so that it is difficult to localize the high ratios to specific bands.

Aside from the results on gels from the control animals given above a number of other control experiments were run to check shorter term transfer of labeling from plasma to erythrocyte membranes. In one such control experiment, non-labeled erythrocytes were incubated with radioactive plasma for $2 \mathrm{~h}$ and the cells were then washed and ghosts were prepared by our procedure and analyzed by SDS-polyacrylamide gel electrophoresis. The specific activity of the plasma proteins used in this control experiment was ten-fold higher than that of the experimental animals at the time they were killed. Contamination of erythrocyte membrane proteins by label from the plasma was found in all slices of the gel with a small peak corresponding to the major peak of the gel electrophorogram. This contamination was barely above background levels and was too small to play any role in the deviation in labeling ratios found at the lower end of the gels from the experimental animals.

In another control study an animal was killed $8 \mathrm{~h}$ after the injection of radioactive L-leucine. This is a time at which plasma protein labeling is near maximum but also before any significant number of labeled erythrocytes should appear in the peripheral blood. In the washing technique the top layer of packed red blood cells was discarded. The reticulocytes concentrate in the top layer, being of lower density than mature erythrocytes [15] so any radioactivity found in the ghosts should be almost entirely due to contamination or exchange with plasma. No evidence of significant uptake of label by ghosts was obtained, the specific activity of ghost proteins being $144 \mathrm{dpm} / \mathrm{mg}$ whereas that of plasma proteins was $19600 \mathrm{dpm} / \mathrm{mg}$ protein.

\section{Discussion}

The results show that for the period of observation involved, most of the membrane proteins behave like hemoglobin which has lifespan kinetics. This, coupled with the fact that plasma proteins show rapid turnover, suggests that $r$ ) exchange occurs between plasma proteins and the erythrocyte membrane. It is possible that a protein which shows very rapid turnover (one day or less) 
might not have been detected by the double-isotope method as used in this study since its specific radioactivity would have decreased to an undetectable level. However, some indication of its presence should have been observed in control experiments where possible exchange between plasma proteins and erythrocyte ghost proteins was tested in vivo and in vitro: both types of experiments gave negative results. The results also indicate that a few small membrane proteins show turnover. The double-isotope technique cannot provide the information required to make the distinction between true turnover and apparent turnover. However, on the basis of results which indicate that exchange between plasma proteins and the erythrocyte membrane is practically non-existent and knowing that the red blood cell has lost its capacity to synthesize proteins [3], it seems most likely that those components of the membrane are removed and are not replaced. If that is so, one would expect that the amount of membrane protein/cell would be less in older cells. This has been reported in a recent study in which erythrocytes of increasing density (increasing age) were found to have a decrease of their membrane protein content [11].

Although there is a suggestion that the region of apparent turnover may consist of two peaks (see experimentals $\mathrm{A}$ and $\mathrm{C}$ in Fig. 2) the region of increased ratio is broad and it is difficult to localize it to any bands. It appears to overlap the region where molecules of molecular weights in the range of 25 000-40 000 fall which is just below where the actin-like proteins fall in electrophorograms of human erythrocyte ghost proteins [16]. For human erythrocytes the upper part of this region contains glyceraldehyde-3-phosphate dehydrogenase (band 6 , molecular weight 35000 ) [16], but we do not known of any other known proteins that fall in this area.

The apparent turnover process observed in this study seems specific: it could result from the activity of the proteases associated with the erythrocyte membrane [17-19] but more information is needed to show that these proteases act on the presumed substrates; a second alternative could be that these proteins, because of their particular location in the membrane and/or because of their particular type of interaction with other membrane components, are 'squeezed' out of the membrane as a result of changes occurring during the ageing process.

\section{References}

1 Schimke, R.T. and Doyle, D. (1970) Annu. Rev. Biochem. 39, 929-973

2 Berlin, N.I. and Berk, P.D. (1974) in The Red Blood Cell (Surgenor, D.M., ed.), pp. 957-1019, Academic Press, New York

3 Marks, P.A., Burka, E.R, and Schlepsinger, D. (1963) Proc. Natl. Acad. Sci. U.S. 48, $2163-2171$

4 Wilner-Zehavi, G.I. and Mager, J. (1966) Blood 27, 319-327

5 Langdon, R.B. (1974) Biochim. Biophys. Acta 342, $213-228$

6 Carey, C., Wang, C. and Alaupovic, P. (1975) Biochim. Biophys. Acta 401, 6-14

7 Fairbanks, G., Steck, T.L. and Wallach, D.F.H. (1971) Biochemistry 10, 2606-2617

8 Maurer, H.R. (1971) Disc Electrophoresis and Related Techniques of Polyacrylamide Gel Electrophoresis, p. 1, de Gruyter, New York

9 Anson, M.L. and Mirsky, A.E. (1932) J. Gen. Physiol. 16, 59-63

10 Lowry, O.H., Rosebrough, N.J., Farr, A.L. and Randall, R.J. (1951) J. Biol. Chem. 193, 265-275

11 Cohen, N.S., Ekholm, J.E., Luthra, M.G. and Hanahan, D.J. (1976) Biochim. Biophys. Acta 426 , 101-122 
12 Bioanchi, R.B., Mariani, G. and McFarlane, A.S. (1976) Plasma Protein Turnover, Macmillan Press, Ltd., London

13 Jacquez, J.A., Foster, D.M. and Shanahan, M.F. (1978) Anal. Biochem. 84, 19-36

14 Bennett, C.A. and Franklin, N.L. (1961) Statistical Analysis in Chemistry and the Chemical Industry, John Wiley and Sons, Inc., New York

15 Danon, D. and Marikovshy, Y. (1964) J. Lab. Clin. Med., 64, 668-674

16 Steck, T.L. (1974) J. Cell Biol. 62,1-19

17 Moore, G.L., Kocholaty, W.F., Cooper, D.A., Gray, J.L. and Robinson, S.L. (1970) Biochim. Biophys. Acta 212, 126-133

18 Bernacki, R.J. and Bosman, H.B. (1972) J. Membrane Biol, 7, 1-14

19 Tokes, Z.A. and Chambers, S.M. (1975) Biochim. Biophys, Acta 389, 325-338 